\title{
Women Entrepreneurship in Global perspective with Reference to India
}

\author{
Chaitanya Kalidindi, P Girijasri
}

\begin{abstract}
Entrepreneurship - An Economic Transformation. Entrepreneurs are Born and Entrepreneurs are Made. Entrepreneur is an individual who has a vision and generates an action plan to accomplish it. Empowering the Global economy with Women Entrepreneurs have blasting quickly. As of now, the number of women entrepreneurs has phenomenal level of growth. This article deals with the Evolution of Women entrepreneurs, their rapid growth, challenges they face and different platforms encouraging women entrepreneurs at global level with respect to India.
\end{abstract}

Key words: Women Entrepreneurship, Economic Transformation, Women Empowerment.

\section{INTRODUCTION}

Entrepreneur: The word Entrepreneur gets from the French word entre, signifying 'between' and prendre suggesting 'to take'. Businessman was from the outset used to portray people who 'risk everything' among buyers and sellers or who 'endeavor' any task, for instance, beginning another endeavor.But, it is difficult to give accurate definition to the term 'Specialist '. Different scientists from different requests see and interpret Entrepreneur from their very own points of view. Some monetary examiner geniuses portrays an Entrepreneur as one who brings resources, work, material and various assets into mixes that make their worth more observable than already and moreover one who starts changes, progressions and another solicitation.

A Psychologist portrays an Entrepreneur as an individual who is regularly dictated by some forces, which create a desire to achieve something.

Management visionaries define Entrepreneur as a person who has a vision and generates plan of action to accomplish it.

Entrepreneurship:

it's miles the technique of creating something innovative with charge with the resource of dedicating the vital time and effort, assuming the accompanying economic, psychic and social dangers and receiving the rewards of monetary, pleasure and freedom.

\section{HISTORY OF ENTREPRENEURSHIP}

It is a fact, that Entrepreneurship started way back 20,000 year ago. Man started this with hunting stage to fulfill the basic need of food to Transformational stage which is changing the world in all aspects. The big shift in

Revised Manuscript Received on December 22, 2019.

* Correspondence Author

Chaitanya Kalidindi, Dept. of MBA, MRECW

Chaitu.kalidindi@gmail.com

P Girijasri, Asst. Professor, Acharya Nagarjuna University, Guntur

sri.pulikam@gmail.com
Entrepreneurship took place during Agricultural and Industrial Revolution. One of the pivotal developments in the history of Entrepreneurship was invention of Money. The Currency completely winded up the Barter System and changed the fate of Entrepreneur.

\section{ENTRY OF WOMEN ENTREPRENEURS AT GLOBAL PERSPECTIVE:}

For many Years, women's role in business and hands was resolute by the cultural notions regarding women's applicable role in society. 'The cult of True Womanhood' within the early nineteenth century determined that women's correct place was reception which they may best serve the political and social wants by dedicating their energies to the creation of a wholesome and nurturing house. The concept of domesticity within the public arena formed the perception of what kinds of jobs were "proper" for women, who required to figure outside their homes and family farms. These factors restricted the avenues for women entrepreneurship and determined that women were fitted to choose few occupations only.

Later Urbanization redefined women's place in economy.During the Progressive Era, though women were propelled into the force, very little chance was provided for the institution of inventive enterprises. Madame C. J. Walker is one such enterpriser who took advantage of the commercial revolution. She was the instigator of hair care product and required the creation of the railroad and telegraphs to be ready to communicate effectively and establish the network that enabled her in turning into one amongst the foremost productive business women of her time.

\section{IDEA OF "GIRLS" AS AN ENTREPRENEUR IN INDIA:}

India is one of the fastest growing economies and the importance of entrepreneurship is discovered out across the Globe.

"girls Entrepreneurship" method it's miles an act of organisation ownership and organization introduction that empowers ladies in an effort to increase their monetary energy similarly to their popularity in society. ladies-entrepreneurs were creating a massive impact in all most every phase of the monetary system.

"Empowering ladies is a prerequisite for developing an outstanding u . s . a ., while women are empowered, society with balance is confident. 
Empowerment of ladies is crucial as their price device ends in the development of a exceptional own family, society and in the end an extremely good kingdom." - APJ ABDUL KALAM

\section{V.GROWTH OF WOMEN ENTREPRENEURSHIP}

\section{Global Perspective}

Women making their mark in business, all around the world. Slowly but steadily, women in business statistics show a lot of progress. Women in business have a major impact on the world economy.

There are so many researchers conducted on impact of women entrepreneurs on Global economy, result of every research states that women entrepreneurs are making their mark in Global economy. A recent research by Boston Consulting Group clearly states that if female entrepreneurs also have same opportunities like male entrepreneurs, the Global economy would have accelerated by 5 trillion dollars.

Women entrepreneurs at global level

\begin{tabular}{|l|l|}
\hline COUNTRY & PERCENTAGE \\
\hline INDIA & 31.6 \\
\hline USA & 45 \\
\hline UK & 43 \\
\hline INDONESIA & 40 \\
\hline BRAZIL & 45 \\
\hline SRILANKA & 35 \\
\hline
\end{tabular}

supply: ladies marketers in India, Arakeri, V. Shanta national 5a3450a772b83f15eb04e7f12335971c Referred magazine of studies in Arts and schooling

As in keeping with test on girls marketers in INDIA by using Banking on girls in 2013, on a median extra than a 3rd of worldwide businesses have women marketers.Indian attitude "An organization owned and managed with the resource of a women having a minimum monetary interest of $51 \%$ of capital and giving at least fifty one \% of the employment generated with the useful resource of the business enterprise 5a3450a772b83f15eb04e7f12335971c girls." - government of India. Entrepreneurship is developing step by step over the last decade; the contribution of ladies is as parallel as guys.there are such a lot of influential women marketers in India.

1. Indu Jain -Chairperson of Bennet, Coleman (TOI).

2. Indira Nooyi - Former CEO of PEPSICO.

3. KiramMazumdar Shaw - Chairperson of Biocon.

4. VandanaLuthra - Founder of VLCC

5. RichaKar - Co-Founder of Zivame.

India can advance its growth rate through encouraging women entrepreneurs. In a recent survey, World Bank says that India will have drastic impact on GDP if they boost more women entrepreneurs.

\section{Women Entrepreneurs Registered In India}

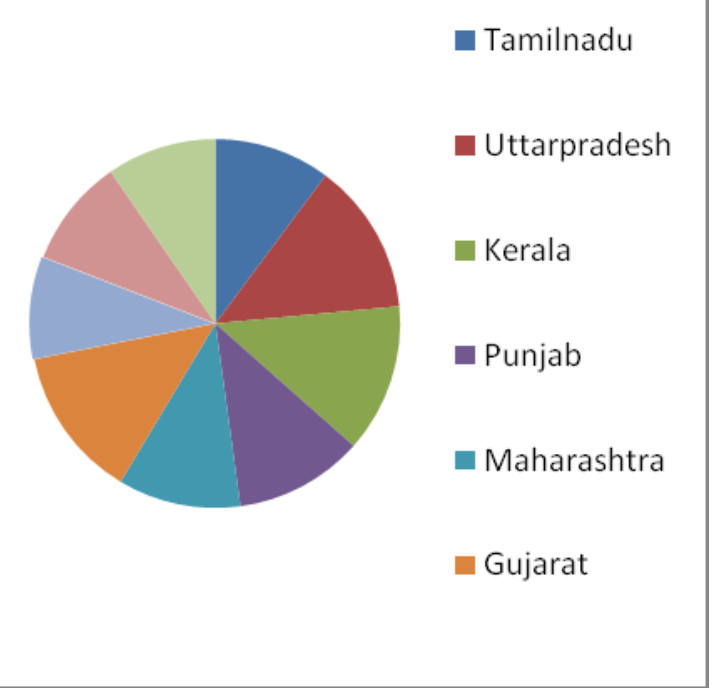

Source: Report of MSMEs, 12th Five year plan2012-2017

Challenges toWomen Entrepreneurs

There are so many challenges for women entrepreneurs to start the business and to run it.

- Access to Finance

- Lack of Family support

- Socio cultural barriers

- Risk taking ability

- Social Discrimination

- Lack of investors Trust.

- Lack of Entrepreneurial training

The reasons behind these challenges are because, they are WOMEN. Even in $21^{\text {st }}$ century also, if a bus is driven by a female driver people will doubt her capabilities and some people even they won't get in to the Bus.

\section{PLATFORMS TO WOMEN ENTREPRENEURS IN INDIA}

Setting up a Platform (WEP) to advance and boost up women entrepreneurs in India took seed at together by NITI Aayog in organization with the Government of the United States of America.Just 13.76 percent of the absolute business people in India are women, as indicated by information by Startup India. There are simply around 8 million female business people, however the quantity of male business visionaries has crossed 50 million. The schemes which encourage women entrepreneurs are as follows

- Annapurna Scheme

- Stree Shakti Package for women entrepreneurs

- Cent Kalyani Scheme

- Mudra Yogana Scheme

- MahilaUdyamNidhi Scheme

- Dena Shakti Scheme

- Orient MahilaVikasYojana Scheme

- BharatiyaMahila Bank Business Loan 


\section{Findings of Study:}

- Irrespective of country, still Gender Biasism is there.

- People didn't have proper awareness about the Government initiatives.

- Lack ofknowledge to women entrepreneurs.

- Women entrepreneurs are not being taken seriously.

- Low risk taking ability of women.

\section{SUGGESTIONS}

- Authorities need to initiate attention applications to change the thoughts-set of human beings toward women marketers

- Particular Entrepreneurship schooling have to be designed for ladies entrepreneurs.

- Authorities ought to inspire ladies entrepreneurs through giving financial incentives.

- Extra massive sort of girls need to decide Entrepreneurship as a career.

- Authorities need to cope with women as particular goal organisation in all developmental packages.

\section{CONCLUSION:}

This report emphasized the role and size of women entrepreneurs worldwide. One must realize women entrepreneurs are major contributing factors in overall economic development of any nation. To encourage entrepreneurial culture, Government must design customized policies and programs. Women entrepreneurs must mould their skills to meet the challenges. "Empowering women is an essential issue for developing a wholesome nation, while ladies are empowered, we are able to guarantee stable society. Strengthening of girls is crucial as their rate machine results within the development of an amazing circle of relatives, society and in the end an great kingdom." finally, women have to select Entrepreneurship not by using danger but through choice.

\section{REFERENCES}

1. Allen S \& Truman C (1993). Women in Business: perspectives on women entrepreneurs, Intl Thomson Business Pe.

2. Intercontinental Journal of Human Resource Research Review ISSN:2320-9704 - Online ISSN:2347-1662.

3. Brush C (1992) " Research on women business owners: past trends a new perspective and future directions", entrepreneurship theory and practice 16(4).5-30.

4. Gupta C B \& Srinivasan N P(2009), Entrepreneural development, Sultan Chand\& sons. 